UDC 2:008:37; IRSTI 09.00.13

https://doi.org/10.47526/habarshy.vi1.380

\author{
T.K. ABDRASSILOV ${ }^{1}$, Zh.Y. NURMATOV ${ }^{\square 1}$, K.K. KALDYBAY ${ }^{2 *}$ \\ ${ }^{1}$ PhD, Acting Associate Professor of Khoja Akhmet Yassawi International Kazakh-Turkish University \\ (Kazakhstan,Turkistan),e-mails: turganbay33@mail.ru; zhakhangir.nurmatov@ayu.edu.kz \\ ${ }^{2}$ PhD, Senior Lecturer of Khoja Akhmet Yassawi International Kazakh-Turkish University \\ (Kazakhstan,Turkistan),e-mail: kaldibaykaynar@list.ru
}

\title{
THE IMPORTANCE OF NATIONAL IDENTITY AMONG YOUNG PEOPLE IN KAZAKHSTAN
}

This study intends to explore the salience of national identity for young people from the perspective of 'commitment and loyalty' to their nation. The uniqueness of this study is that it provides the opportunity to observe the salience of civic, ethnic, and cultural features of national identity in Kazakhstan.

This article has examined the importance of national identity theoretically and critically reviewed the literature on this theme. For the case study, a small survey was conducted in order to evaluate the role of inclusion in shaping national identity among young students.

An academic implication of this research entails further research on the salience of belonging and sense of attachment to national identity among young people in other cosmopolitan cities of Kazakhstan, such as Almaty, Nur-Sultan and Atyrau, where the effect of globalisation is more prevalent and the Kazakh customs and traditions less noticeable in order to make a comparative evaluation.

In this context, the authors consider the importance of national identity for young individuals by analysing the theories on nations and nationalism, specifically emphasising the relation between individuals and their nations. Analysis is complemented by a short survey on the subject of national identity, which was carried out among students of the Kazakh-Turkish International University in Turkistan, Kazakhstan.

Keywords: Nation, national identity, nationalism, youth, Kazakhstan, Kazakh people.

\section{Т.К. Абдрасилов ${ }^{1}$, Ж.Е. Нурматов ${ }^{1}$, Қ.К. Қалдыбай ${ }^{2}$ \\ ${ }^{I}$ PhD, Қожа Ахмет Ясауи атындавы Хальққаральққ қазақ-түрік университетінің доиент м.а. (Қазақсстан, Түркістан к..), e-mails: turganbay33@mail.ru; zhakhangir.nurmatov@ayu.edu.kz ${ }^{2} \mathrm{PhD}$, Қожа Ахмет Ясауи атындавы Халықаральққ қазақ-түрік университетінің ава оқытушысы (Қазақ̧стан, Түркістан к̧.), e-mail: kaldibaykaynar@list.ru}

\section{Қазақстанда жастар арасындағы ұлттық бірегейліктің маңыздылығы}

Зерттеудің мақсаты ұлттық бірегейліктің жастардың өз ұлтына деген «адалдық және шынайылық» тұрғысынан маңыздылығын зерттеуге бағытталған. Бұл зерттеудің ерекшелігі-Қазақстандағы ұлттық бірегейліктің азаматтық, этникалық және мәдени сипаттамаларының маңыздылығын көруге мүмкіндік береді.

\section{* Бізге дұрыс сілтеме жасацыз:}

Abdrassilov T.K., Nurmatov Zh.Y., Kaldybay K.K. The Importance of National Identity Among Young People in Kazakhstan // Ясауи университетінің хабаршысы. - 2021. - №1 (119). - Б. 64-74. https://doi.org/10.47526/habarshy.vi1.380

\section{*Cite us correctly:}

Abdrasilov T.K., Nurmatov Zh.Y., Kaldybay K.K. The Importance of National Identity Among Young People in Kazakhstan // Iasaýl ýnıversitetiniń habarshysy. - 2021. - №1 (119). - B. 64-74. https://doi.org/10.47526/habarshy.vi1.380 
Бұл мақалада ұлттық бірегейліктің маңыздылығы теориялық тұрғыдан зерттеліп, тақырып бойынша әдебиеттерге сыни шолу жасалады. Тақырыптық зерттеу үшін жас студенттер арасында ұлттық бірегейлікті қалыптастыруға қатыстылық рөлін бағалау мақсатында шағын сауалнама жүргізілді.

Зерттеудің академиялық маңыздылығы жаһанданудың әсері басым болатын және салыстырмалы бағалау үшін қазақтың әдет-ғұрпы мен дәстүрі онша көрінбейтін Алматы, Нұр-Сұлтан және Атырау сияқты Қазақстанның басқа космополиттік қалаларында жастардың ұлттық бірегейлікке деген сенімі мен сезімінің маңыздылығын одан әрі зерттеуді қажет етеді.

Зерттеу жұмысы адамдар мен олардың ұлттары арасындағы қатынастарға ерекше назар аудара отырып, ұлттар мен ұлтшылдық туралы теорияларды талдау арқылы ұлттық бірегейліктің жастар үшін маңыздылығын қарастырады. Сондай-ақ бұл зерттеу Қазақстанның Түркістан қаласындағы Халықаралық қазақ-түрік университетінде студенттер арасында жүргізілген ұлттық бірегейлік туралы қысқаша сауалнамамен толықтырылды.

Кілт сөздер: ұлт, ұлттық бірегейлік, ұлтшылдық, жастар, Қазақстан, қазақ халқы.

\author{
Т.К. Абдрасилов ${ }^{1}$, Ж.Е. Нурматов ${ }^{1}$, К.К. Калдыбай ${ }^{2}$ \\ ${ }^{I} \mathrm{PhD}$, и.о. доиента Международного казахско-туреикого университета \\ имени Ходжи Ахмеда Ясави (Казахстан, г. Туркестан) \\ e-mails: turganbay33@mail.ru; zhakhangir.nurmatov@ayu.edu.kz \\ ${ }^{2} \mathrm{PhD}$, старший преподаватель Международного казахско-туреикого университета \\ имени Ходжи Ахмеда Ясави (Казахстан, г. Туркестан), е-таil: kaldibaykaynar@list.ru
}

\title{
Важность национальной идентичности среди молодежи в Казахстане
}

Данное исследование направлено на изучение важности национальной идентичности для молодых людей с точки зрения «приверженности и лояльности» своей нации. Уникальность исследования заключается в том, что оно дает возможность увидеть значимость гражданских, этнических и культурных особенностей национальной идентичности в Казахстане.

В статье теоретически исследована важность национальной идентичности и дан критический обзор литературы по данной теме. Для тематического исследования был проведен небольшой опрос, чтобы оценить роль вовлеченности в формировании национальной идентичности молодых студентов.

Академическое значение этого исследования влечет за собой дальнейшие исследования значимости принадлежности и чувства привязанности применительно к национальной идентичности среди молодых людей в других космополитических городах Казахстана, таких как Алматы, Нур-Султан и Атырау, где влияние глобализации более распространено и казахские обычаи и традиции менее заметны для сравнительной оценки.

В этом контексте авторами рассмотрена важность национальной идентичности для молодых людей, проведен анализ теорий о нациях и национализме с особым упором на отношения между людьми и их нациями. Анализируемый материал дополнен результатами краткого опроса на тему национальной идентичности, проведенного среди студентов Международного казахско-турецкого университета имени Ходжи Ахмеда Ясави в Туркестане (Казахстан).

Ключевые слова: нация, национальная идентичность, национализм, молодежь, Казахстан, казахский народ. 


\section{Introduction}

While theoretical statements assert the significance of national identity in the lives of people in contemporary states, empirical research fails to provide compelling results to reveal the apathy or disregard of young Britons towards national identity [1, p. 323]. National identity and nationalism as two distinct dimensions - are an integral part of an individual's acknowledgement of their membership to a nation. Being aware of one's own membership would allow understanding of one's place in the world. The young people of Kazakhstan will shape the country in the short term; they are the future of the country, and seek to understand who they are and endeavour to develop their own identity [2, p. 5] by searching for what defines their national identity. In this sense, studying the salience of national identity and its perceptions, especially among young people in Kazakhstan, is of enormous importance. Despite fast-growing literature on national identity, the young or student-related context has been said to be somewhat lacking [2, p. 6]. Indeed, to the best of this author's knowledge, among the plethora of literature there has been found little empirical research conducted to evaluate national identity from the perspective of 'commitment and sense of belonging' among young people in Kazakhstan.

\section{Theoretical framework on the concept of 'a sense of attachment' to national identity}

A significant amount of literature on nationalism suggests that national belonging is strong and durable. Both nationalists and observers of nationalism see nations as natural societies that require the allegiance of their citizens by birth and communication [1, p. 325]. Connor [3, p. 375], referring to the sentiments of kinship engendered by the ethno-nationalist, claims that attachments and membership which are expressed in many respects as unthinking or irrational are filled with a strong feeling that individuals would be prepared to kill and/or to die for them, suggesting that the readiness of individuals to sacrifice their lives for nationalistic reasons could be considered as the crucial indicator of the seriousness of their attachment towards their imagined nation $[4, \mathrm{p} .56]$. Although most individuals find themselves to be members of living nation-states [5, p. 62], the majority of them do not demonstrate personal feelings or support to any political ideological movement that might be considered 'nationalist'. Nonetheless, the sense of national attachment can be observed from their speech and behaviour that implicitly refer to a national allegiance, but not to nationalism [6, p. 38], indicating the overt distinction between national identity and nationalism which is able to influence and form [7, p. 378] but cannot generate or produce a sense of allegiance. While Anthony Smith, who is an advocate of perennialist theory, suggests that a sense of commitment takes its root from historical and traditional identities, suggesting that a sense of commitment is closely related with historical identities. Modernist theorist Gellner [5, p. 63] undervalues the influence of ancestral ideologies and historical identities by arguing that nationalism, which is politically functional, is a by-product of cultural homogenisation in modern states. Moreover, he contends that the formation of nationhood as the cultural and political basis is realised through the allegiance to modern states. In other words, individuals must comprehend or be indoctrinated that they are representatives of a nation.

However, Smith [7, p. 380], contrary to this claim, argues that most modern states have historical origins in ethnie that have generated a feeling of commitment and allegiance for hundreds of years prior to the emergence of modern nations. For example, historical memories, national symbols such as flags, anthems, popular heroes and unique customs, traditions that are shared by the individuals of a society, make a direct appeal to historical identity. His illustration portrays national identity as being capable of having a profound impact on the people, which remains important and powerful to explain the feeling of commitment that is strengthened by collective cultural values and identities. However, Fenton [1, p. 325] seems in disagreement with this claim by stating that this does not mean all these activities are enjoyed or regarded as supremely significant, as participation in these activities can be just mere routine and repetition. Attempting to find the answer to the question of the salience of belonging, Brubaker [8] argues that ethnic nationalisms 
generate strong feelings of commitment and loyalty. However, Fenton [1, p. 326] does not seem to be in agreement with this assertion, arguing that a distinct perception of nationhood can also be gained from civic nationalism, using France and the USA as an example. In order to elaborate further on the distinction between ethnic and civic identity, Tartakovsky (2010) maintains that there are two parts of attachment to a nation: instrumental, and symbolic (or sentimental). For Tartakowskyi, instrumental allegiance represents the degree of satisfaction of individuals with the manner by which the country operates, the effectiveness of its social, political, and economic structures, and the perceived potential of such structures to sustain instrumental benefits to the people of the nation and to fulfil their specific needs. Such needs are mainly economic, but the nation in particular, as it protects from external threats in the form of a state. The instrumental allegiance to the nation encourages people to engage in community associations, thereby improving their unique status within the system and fulfilling both the developmental and subsistence needs [9].

Calhoun follows the same line of argument, claiming that the love or feelings towards nations that civic nationalism preaches is required rather than demonstrated, suggesting that this perception of the nation focusses on the legal and territorial dimensions. In other words, in order to become a member of that nation, the commitment of individuals to the political and legal agenda is required. Further, Calhoun suggests that factors such as economic and political powers significantly echo the power that the states and overarching economic activity hold over individuals [10, p. 163]. It is certainly convincing that people acknowledge the role of the state as a political repository for their lives, as individuals become aware of the actions of the government by reading and hearing daily news that allows the connection to be established between the state and citizens. Even tax, insurance, health, and education policies have a certain impact on the daily lives of individuals that make people realise that living in that particular country is an important part of their lives, both socially and personally. Could all these activities such as taking wages, healthcare, and pensions generate the feeling of loyalty or sense of attachment to this country? Looking from the perspective of Symbolic approach or sentimental (primordial) attachment represents the need of individuals to belong, to affirm their identity and to improve their self-esteem by association with the nation. Identification with the nation allows the sharing of one's own personal values as well as being accepted by others who belong to the nation as well. In fact, the emotional attachment to the nation, articulated as an affinity with the nation, gives people a sense of importance and meaning in life, safeguarding them from existential anxieties. This is supported by Tamir [11, p. 15] who reinforces this point of view by explaining civic and ethnic nationalism by alluding to the arguments of Hans Kohn, who claimed that civic nationalism that is based on the liberal and rational way of thinking requires respect towards the freedom of people and human rights, whereas ethnic nationalism is a mystic, religious and ethno-nationalistic approach founded on tribal feelings. Kohn concludes by stating that civic nationalism is a modern political occurrence intended to promote the personal identity that is typical of liberal-minded Western states; in contrast, ethnic nationalism is predicated on language, folk culture, and ethnicity, and thus is emotional and driven by kinship and attachment. However, in contrast to the arguments of both the ethnic and civic approach in addressing the question, Calhoun asserts that the current ideas of nation are connected closely with the modern ideology of the individual, opposing the notion that a nation is a constant pre-national or sub-national society. His argument demonstrates the contradictory stance both to the ethnic and civic explanation about the origins of the sense of belonging, suggesting that the relationship between nation and individual is constructed directly - meaning there is no need for the involvement of cultural and historical identities. Further, he maintains that belonging to nation can be realised without being a member of any other communities or groups. This is supported by Geertz [12, p. 235] and Simons, who both claim that national membership - particularly in democratic politics - requires the separation of individuals from local and sub-state societies, as enclosure within local and sub-state communities poses a menace both to the nationhood and 
democracy. Thus, Greenfield and Chirot conclude by claiming that national identity establishes the basis of identity - in other words, the identity which is assumed to be the core of the individual suggesting that the emotional strength of a national identity is not based on ethnicity and culture but rather a consequence of the direct link between the nation and individual. In an individualistic society, modern nation states appeal directly to the individual. Therefore, there is no need for the individual to negotiate with community, class, family, or area in order to be a member of the nation, and an individual's nationality should be perceived as one of their characteristics [10, p. 164].

To this end, despite the plethora of accounts and arguments of the postmodernist approach regarding the salience of national identity for the individuals, there is no clear suggestion meaning each theory can fit appropriately to the space and time differently depending on the culture and mentality of the community and the individuals within it.

\section{Data collection}

\subsection{Methodology and sample}

This study aims to examine the salience of attachment to national identity of young Kazakhs by applying the quantitative method, which, according to Creswell [13, p. 26], is utilised for an initial and preliminary research as it focuses on the statistics and numbers that provide a view of social reality. A survey was designed and administered using the website https://my.survio.com as a tool. This small research survey was conducted among students of Khoja Akhmet Yassawi International Kazakh-Turkish University, Turkistan, Kazakhstan. Gratitude and appreciation are extended to the students of the University who took part in the survey for their substantial input towards this important research. The questionnaire was administered to 52 students from various ethnic groups, however most were Kazakh students who accounted for almost $62 \%$, followed by Uzbek students who made up $26 \%$ of the sample (see Figure 3). The study included participants of both sexes (see Figure 1): 62\% were female and 38\% male; and 98\% were aged between 18-29, $2 \%$ between $30-45,2 \%$ between $46-60$ years old (see Figure 2 ). The participants' nationality/ethnicity was recognised as $62 \%$ Kazakh, 26\% Uzbek residents of Kazakhstan, 10\% Turkmen, and 2\% Turk (see Figure 3). The author of this article believes that the findings of this study provide reliable data exploring a hypothesis corresponding to research results regarding commitment, as conducted by Sharipova [2, p. 6].

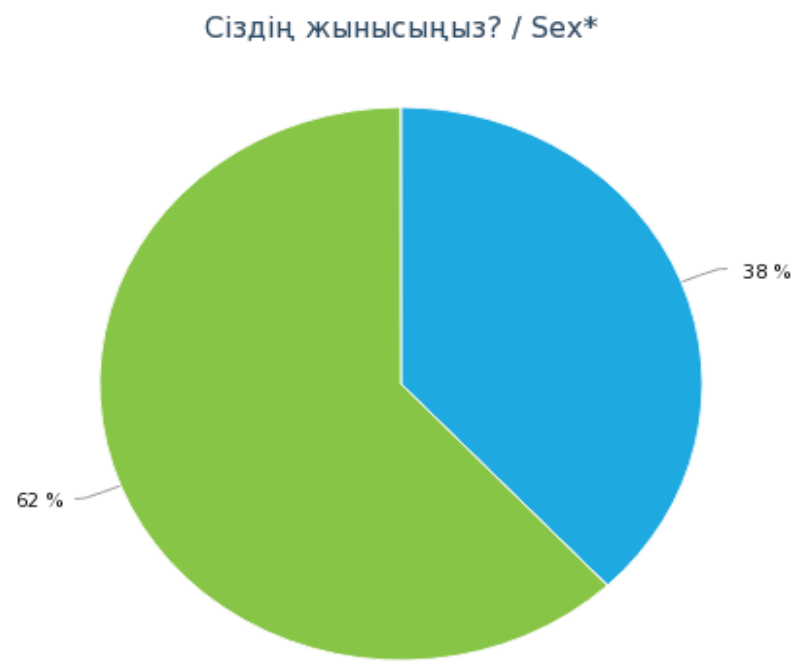

- Ep / Male әйел / Female

Figure 1 - Gender of participants 


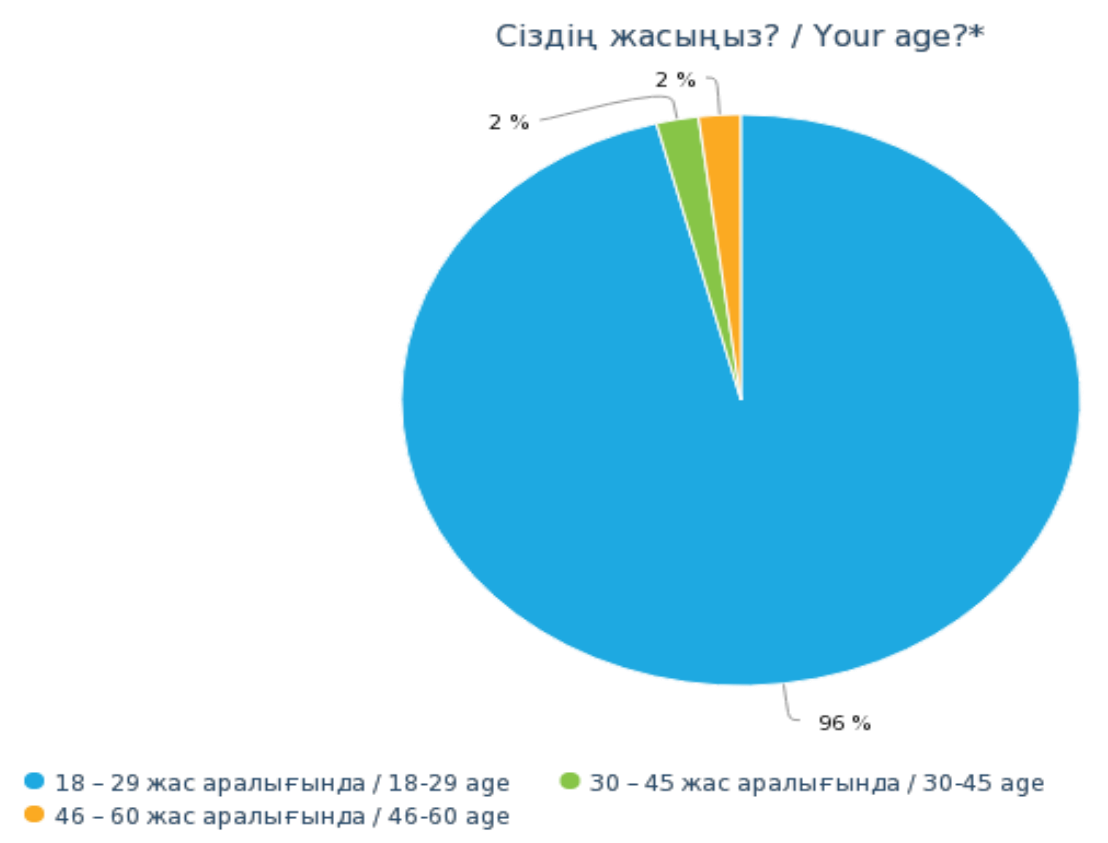

Figure 2 - Age of participants

Сіздің ұлтыңыз? / Nationality?

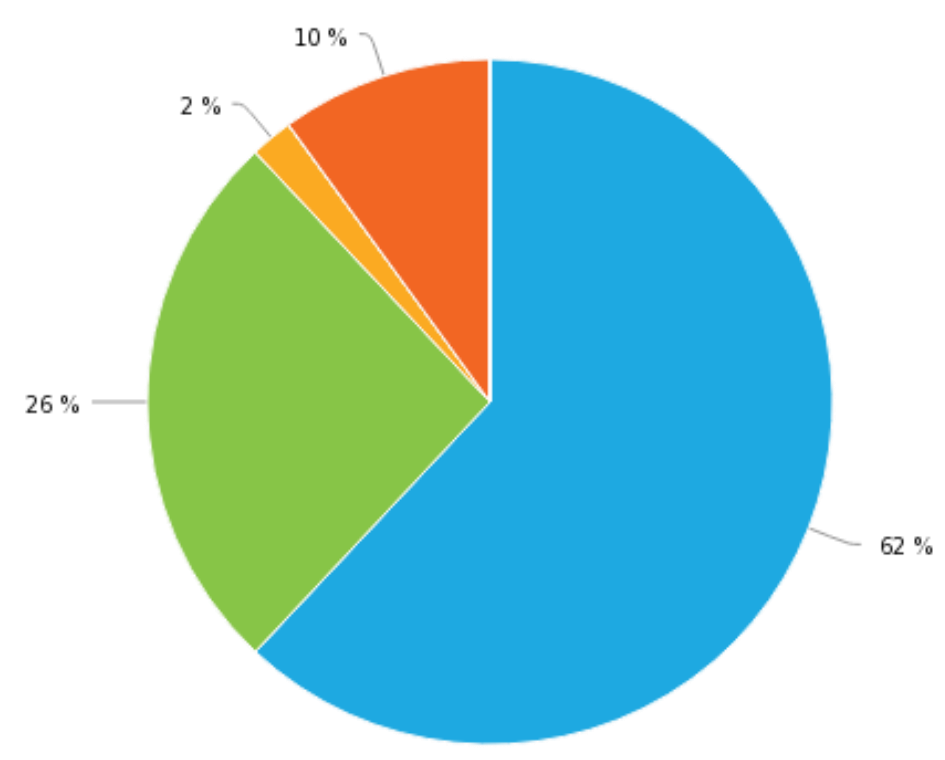

Қазақ/Kazakh

- Өзбек/Uzbek Түрік/Turkish қырғыз / Kirgiz - Түркімен / Turkmen

- Басқа ұлт өкілімін / Other Nationalities

\section{Figure 3 - Nationalities of participants}

\subsection{The questionnaire}

Before commencing the survey, a lecture relevant to the topic of national identity and nationalism was delivered to the students so that they fully comprehended the topic. Then, the questions were presented to students which were multiple choice questions instead of five-point Likert scale type questions, so that they were as straightforward as possible for students. Students 
responded to each question by selecting one of the answers presented to them. The aim of this research was to identify the significance of national identity for the young Kazakh students, especially in terms of the 'sense of belonging', and therefore several commitment-related questions were highlighted in the questionnaire. The following questions were asked:

1. 'Is national identity important in your life?'

2. 'Are you proud of your nationality?'

3. 'Which of these identities would you accept first?'

4. 'Is it important to belong to one nation state?'

\subsection{Analysis and discussion of findings}

The aim of this article is to identify the salience of national identity for young people in Kazakhstan and this will be measured using three important categories. The first is unintended disregard ('don't know, never think about it') and indifference ('it's not that important'); the second is a more explicit indifference and even anti-nationalist attitude ('I hate nationalism', 'I'm just me, anyway'); and a third type of indifference is prioritising the wider identity over national identity ('a citizen of the world'). As this survey was conducted in a province where most of the citizens living there are Muslims, it was anticipated that the majority of the respondents would choose option d) 'yes it is important', as Sharipova [2, p. 6] maintains that with an increase of religiosity, the sense of allegiance to one's nations rise. However, 50\% answered 'yes it is important' (see Figure 4), and the rest $(36 \%, 10 \%$, and $4 \%)$ fit with first category of 'unintended disregard'. This suggests that the sense of attachment and intensity of commitment among young people is still not salient, reflecting the indifference towards national identity through the category of overt disregard. This finding concurs with the hypothesis of Sharipova [2, p. 5], whose survey found that Kazakhstani identity has not been internalised by young people and remains unshaped. With regards to identifying the feeling of taking pride in one's nationality, $76 \%$ answered that they are proud of their nationality which is the highest demonstration, yet opposing the previous answer 'yes it is important', illustrating a contradiction in answering the questions even though both bear the same meaning despite their difference in expression. This shows that when asked about patriotism, young people answered that they felt proud of their allegiance to their nation inherent by birth and socialisation [1, p. 325], which can be assumed as taken for granted. As for their selection among the identities, $56 \%$ chose family identity (Figure 6), the identity that is based on the kinship and blood relations that are innate to 'Kazakhness'. Here, identity is linked with historical identities, and according to Fenton [1, p. 325], a sense of belonging is not stable and fixed which means it could change depending on the circumstances. For example, Libkind [14] contends that individuals have a variety of identities such as family, nationality, gender, and professional identities, and the significance of these identities change over time no matter whether they complement or conflict with each other; this means during severe trials, one identity comes out as the most prominent, overshadowing the other identities. For example, when there is a cross-cultural conflict, the nation-state identity stands out, but if something bad happens to the family or children get sick, family identity comes to the fore.

Moving on to the question of attachment to one nation-state, $68 \%$ of respondents chose the importance of belonging to one nation which suggests that when the culture and history of the nation were mentioned, people unwittingly placed high importance on national identity. Again, this is indicative to the theory of Smith [7, p. 380] who posits that Kazaks link their identity with ancestral ideology and identity. Overall, the results do not correspond with the findings of Sharipova [1, p. 7] who conducted research among young people in 14 regions of Kazakhstan, with the aim of exploring the importance of national identity. Her empirical research revealed that enthusiasm or patriotism toward nations was very weak, suggesting indifference towards national identity by unintended apathy categories 'do not know, never think about it'. 
Although the research found indifference and disregard towards national identity among the young students, the overall results reveal that young students become more enthusiastic and interested when traditional values are mentioned. This has become evident from Figure 7, where $68 \%$ respondents chose the answer 'belonging to the nation' due to the identification with culture and history. The responses chosen and illustrated in Figures 5, 6 and 7 regarding national identity support the hypothesis or assumptions of indifference towards national identity through the categories of unintended disregard and explicit indifference. Again, this may highlight the impact of globalisation and modernisation along with consumerism and individualism on the mentality of the young people of Kazakhstan.

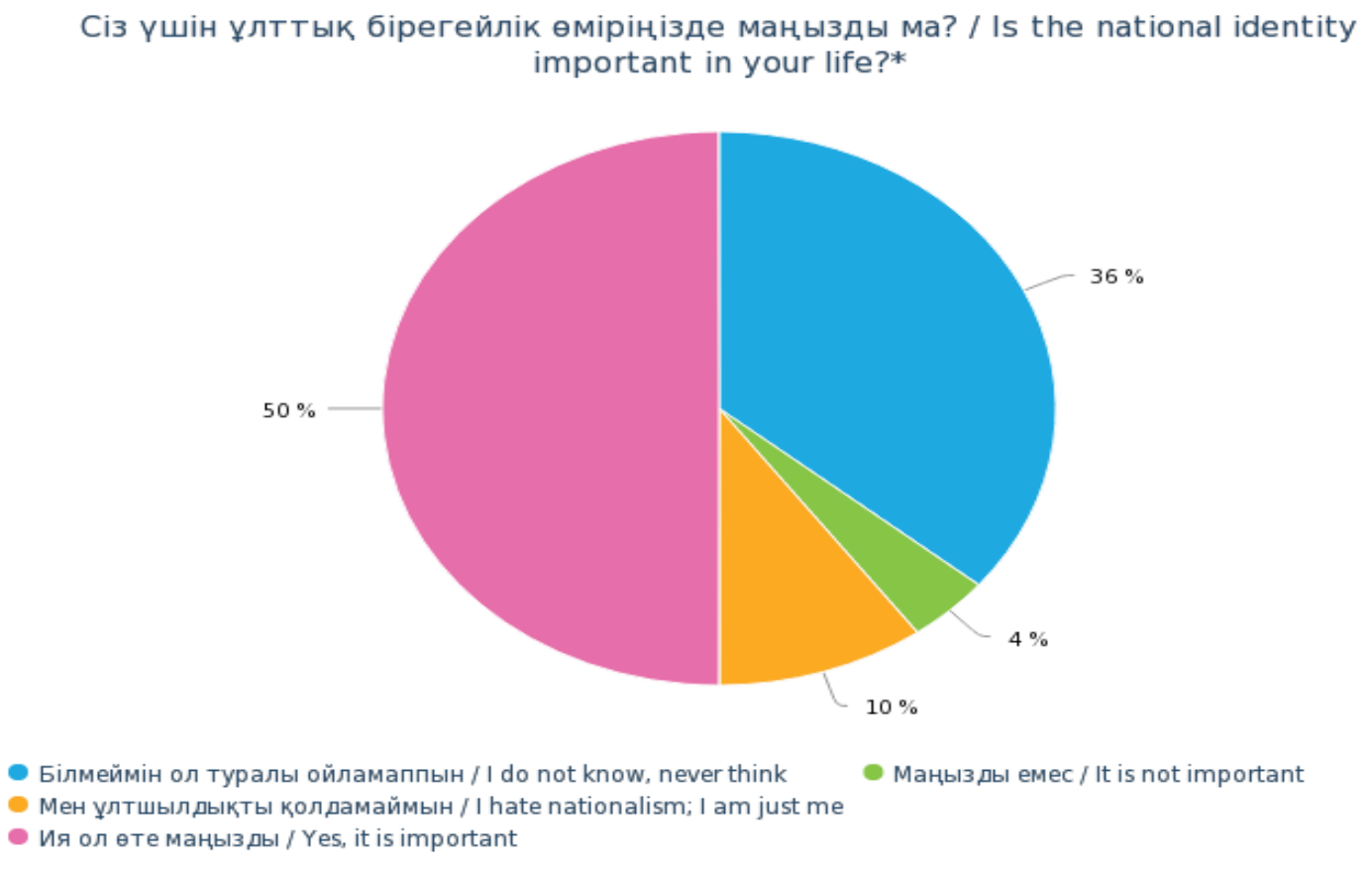

Figure 4 - Importance of national identity

Сіз өз ұлтыңызбен мақтанасыз ба? / Are you proud of your nationality?

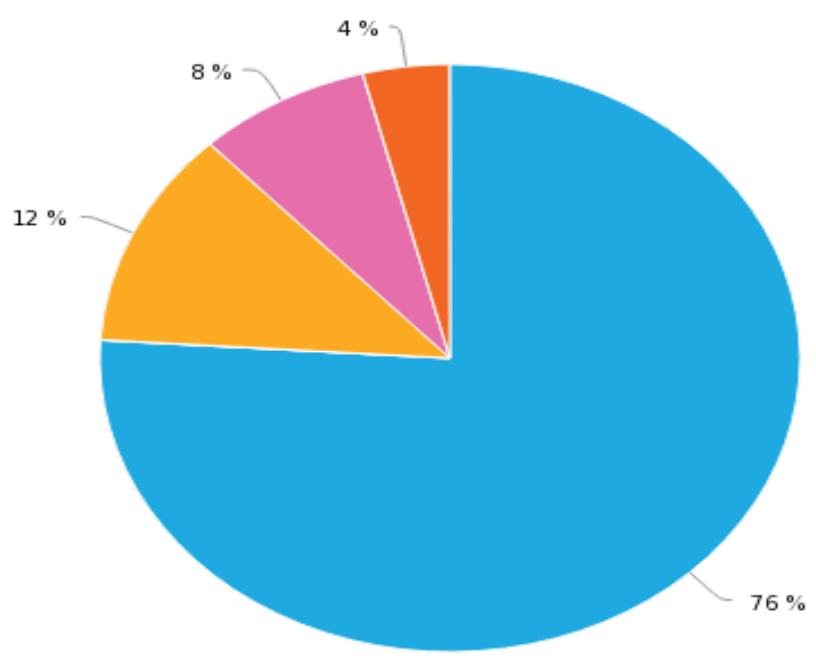

- Ия мақтанамын / Yes, I am proud Маған бәрібір / I do not care

- қазіргі таңда ұлтшылдық маңыз ды емес / Today, nationality is not important

- Ұлтшылдық қақтығысқа әкеп соқтырады / I think it triggers racism

Білмеймін / I do not know

Figure 5 - Views on patriotism/nationalism 
Келесі бірегейліктерден қайсысын бірінші таңдар едіңіз?/ Which of the identities would you accept first?

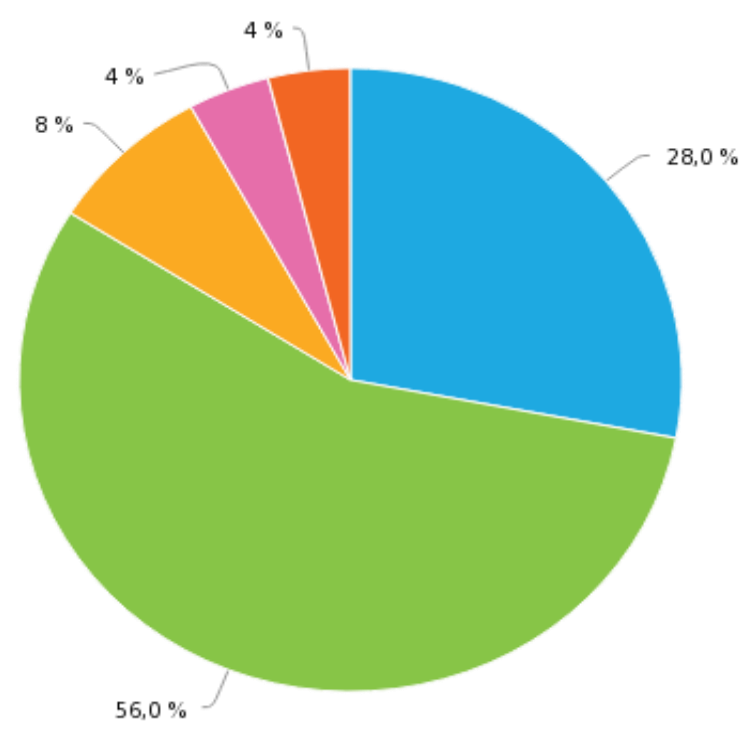

Ұлттық бірегейлік / National identity, nation
қазіргі тұрып жатқан районым / Community where you live currently

\section{Figure 6 - Choosing one identity over others}

Сізге бір ұлттың азаматы болу маңызды ма? / Is it important to belong to one

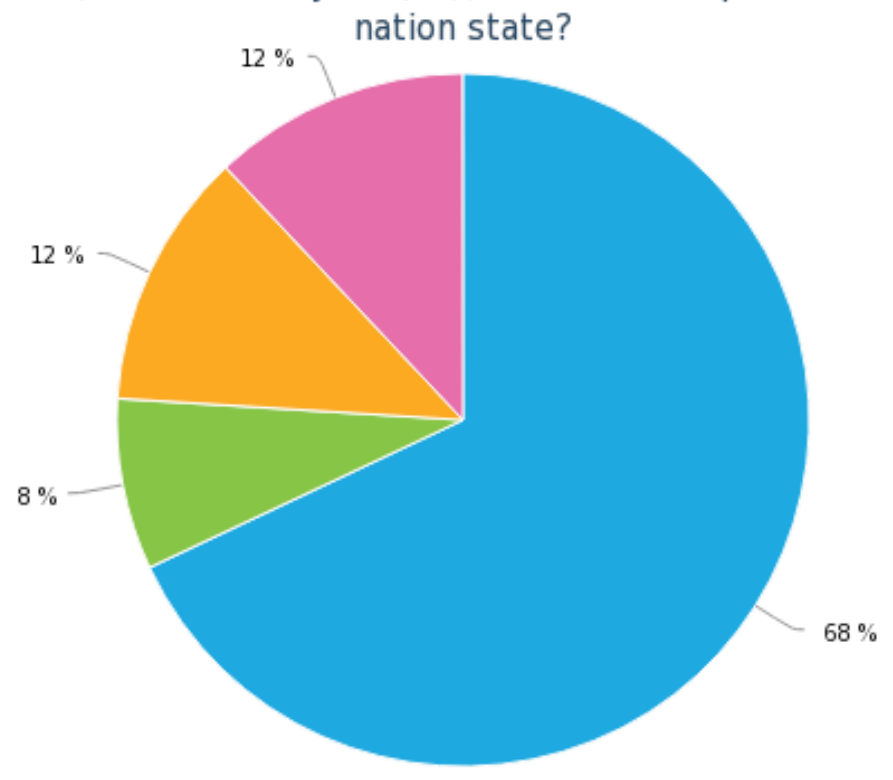

Ия маңызды, мен сол ұлттың тарихы, мәдениеті арқылы таныламын / Yes, it is important. Because I am identified with the history, and culture of that nation.

Жоқ маңызды емес, себебі мен жеке индивид, адаммын / No, it is not. I am just me

- Мен бір мемлекет азаматы емес, әлем азаматы болғым келеді.(Мобилді) / I do not want to belong to one nation, but rather I want to be a citizen of the world. (Mobile)

- Менің қай жерде әлеуметтік-экономикалық жағ дайым жақсы ең маңыз ды сол / Where my socio-economic conditions is good that place is important for me

Figure 7 - Importance of belonging to one nation state 


\section{Conclusion}

This article has examined the importance of national identity theoretically and critically reviewed the literature on this theme. For the case study, a small survey was conducted in order to evaluate the salience of membership to national identity among young students. The survey was carried out to support or reject the research assumption or hypothesis of whether young Kazakh people feel a sense of attachment to national identity or not. Fifty-two respondents took part in the survey online. The survey results appear to support the research of Kuzembayeva et al. [15] whose research found that approximately $81 \%$ of students were aware of the Kazakh culture, having revealed that most students showed enthusiasm towards traditional values. This is evidenced by the participants' decision to select family identity over other identities, accounting for $56 \%$ of the total, due to the blood relations, kinship, and genealogical ties that have roots in history and culture, validating the theory of Smith in the Kazakh context.

A practical implication is that the fundamental research question or hypothesis that has been suggested could contribute to the formation of civil society and the reinforcement of democracy during the nation-building process. An academic implication of this research entails further research on the salience of belonging and sense of attachment to national identity among young people in other cosmopolitan cities of Kazakhstan, such as Almaty, Nur-Sultan and Atyrau, where the effect of globalisation is more prevalent and the Kazakh customs and traditions less noticeable in order to make a comparative evaluation.

A limitation of this article is that its findings may not be generalised, as firstly this small survey was conducted in a Kazakh-dominated area where traditional Islamic and Kazakh customs are deeply engrained; and secondly, as has been mentioned, the survey has been carried out among students and in a small city. Another limitation is that the project used a quantitative design, when to some extent a mixed methods approach involving both qualitative and quantitative methods would be appropriate in order to give a broader understanding and improve validation [16]. Combining qualitative and quantitative methods help a researcher not only to address the research questions, but also enables unexpected results to emerge [17].

\section{BIBLIOGRAPHY}

1. Fenton, S. Indifference towards national identity: What young adults think about being English and British. // Nations and Nationalism, 13 (2). - 2007. - P. 321-339.

2. Sharipova, D. Youth and Civic national identity. The Nazarbayev Generation: Youth in Kazakhstan. Laruelle, M (ed.). New York: Lexington Books, 2019. - P. 1-21.

3. Connor, W. Beyond reason: The nature of the ethno-national bond. Ethnic and Racial Studies, 16 (3). - 1993. - P. 373-390.

4. Anderson, B. Imagined communities: Reflections on the origin and spread of nationalism. London, New York: Verso, 2006. - 256 p.

5. Gellner, E. Nations and nationalism. Oxford: Blackwell, 1983. -150 p.

6. Thompson, A. Nations, national identities and human agency: Putting people back into nations. Sociological Review, 49 (1). - 2001. - P. 33-55.

7. Smith, A.D. The problem of national identity: Ancient, medieval and modern? Ethnic and Racial Studies, 17 (3). - 1994. - P. 375-399.

8. Brubaker, R. Citizenship and nationhood in France and Germany. Cambridge, MA: Harvard University Press, 1992. - 179 p.

9. Tartakovsky E. National Identity. In: Levesque R.J.R. (eds) Encyclopedia of Adolescence. Springer, New York, NY. - 2011. [Electronic resource]. - Access mode: https://doi.org/10.1007/978-1-4419-1695-2_367

10. Calhoun, C. Nationalism. Buckingham: Open University Press. London. - 1997. - P. 162-164. 
11. Tamir, Y. Not so civic: Is there a difference between ethnic and civic nationalism? Annual Review of Political Science, 22 (1). - 2019. - P. 1-16.

12. Geertz, C. Interpretation of cultures. New York: Basic Books, 1973. -471 p.

13. Creswell, J. Research design: Qualitative, quantitative, and mixed methods approaches. Thousand Oaks: SAGE. - 2003. - 342 p.

14. Liebkind, K. Minority identity and identification processes: A social psychological study: Maintenance and reconstruction of ethnolinguistic identity in multiple group allegiance. Helsinki: The Finnish Society of Sciences and Letters, 1984.

15. Kuzembayeva A., Nurdavletova S., Chukubayev Ye., Baikushikova G. Globalization and cultural attitudes of youth in Kazakhstan. // Global Journal of Sociology. Volume 04, Issue 2. 2014. - P. 23-28.

16. Johnson, R.B., \& Onwuegbuzie, A.J. Mixed methods research: A research paradigm whose time has come. // Educational Researcher, 33 (7). - 2004. - P. 14-26.

17. Bryman, A. Social research methods. $4^{\text {th }}$ ed. Oxford: Oxford University Press, 2012. -809 p. 